a much more general resolution of a general important problem - even if one that is not directly the concern of the scientific community. That even brave people such as the Sakharovs might have been able to accomplish a step towards that goal is naturally a conjecture - and at times like the winter solstice, even people like them will be forgiven for putting Christmassy personal considerations before grand and perhaps unattainable causes.

None of this will much help the scientific academies or the individual members of the scientific community to know more clearly where they should stand on the events of the past few weeks. On the most immediate issues, they have no competence to make pronouncements of a scientific character even if they may choose to be vociferous in other roles. Precisely how the residue of what the Poles used to call Solidarity should be succoured is beyond their competence as scientists (although some, as scientists, may in future think differently of the problems of European defence). The only legitimate opening in this haunting argument for the scientific community is that represented by the hypocrisy of the institute directors from the East, who pretend that all the dreadful things that happen to those who used to be their young men and women are outside their competence. That defence can no longer wash - and it would be better for all concerned if the Soviet authorities would make (as would be their right) a simple rule that those who have berefited from the Soviet educational system must work their passage towards emigration by some system of indenture - so many years of public service for such and such a qualification would at least let people know where they stand, and would be consistent with the principle that sovereign states should be free to decide how to run their affairs. The growing practice of depriving skilled people as a kind of punishment of the right to practise their skills is a loss of more than a Soviet resource, and is offensive. Indeed, it is a disgrace.

\section{British academic agony}

The British government has relaxed pressure on its universities, which may fail to take advantage.

The British government has now agreed to pay the second instalment of the cost of reorganizing and running down the British university system, decreed by the then Secretary of State for Education and Science just over a year ago. During the present academic year (which ends on 31 July 1982), the University Grants Committee has been able to set aside a total of $£ 20$ million to help with the cost of paying off redundant academics. In the following year, there will be a further $£ 50$ million to spend on measures of reorganization in the university system, but the government bravely says that it hopes not all of that will have to be spent on putting academics out to grass. If the Committee of ViceChancellors is to be taken at its first word on the subject (which would be imprudent), the settlement for next year will be totally inadequate to pension off university teachers whose tenure of their jobs cannot be sustained. In reality, of course, the crunch will come in the succeeding financial year, when the universities will have reduced their student numbers to those required of them by the University Grants Committee, and when their urgent need will be to trim their sails for the long haul that will by then seem to lie ahead. But the government has promised to provide a still unspecified amount of money to cover the costs of that year's mayhem; is it hoping that in the meantime (during 1982-83) the universities will have the wit to think of doing novel things, things they have not thought of yet?

The difficulty in understanding the conflict between the British government and the British university system is that it is not so much a conflict between an irresistible projectile and an immovable object as between blancmange and jelly (or jello). The government has discovered, late in the day, that the cost of firing tenured academics is not negligible, but dare not say so. The universities, on the other hand, are so frightened and affronted by what has happened to them in the past year, in particular by the discovery that they have fewer friends than students, that they behave as if they have no choice but to pass on to their paymasters the information that they have gathered from the Association of University Teachers, the mild-mannered labour union capable nevertheless of making a lot of noise, that the cost of any change is bound to be greater than the cost of comfortable no-change. The time has come to ask whether even that seemingly prudent course can be wise.

Like the constituents of other university systems, British universities are naturally jealous of their autonomy. Their jealousy is, however, undimmed even while (as now) they are learning to live with instructions from the University Grants Committee that the numbers of students recruited in various fields should be determined in advance. The conventional statement of academic freedom is that self-governing universities should be free to decide for themselves who should teach what to whom. The difficulty, in present circumstances, is that the who is defined by the survivors now in post, that the what is largely determined by extension and that the to whom, the students, make their own numbers through the medium of the Universities Central Council on Admissions, falling so to speak where the academics lie. The new restrictions on student numbers rob the university system of a further degree of freedom, a loss which collectively the universities have not yet chosen to complain about. They should.

Individually if not collectively, they should also give some serious thought to what the more distant future holds. Although the government has been able to put some kind of limit on the cost of other kinds of higher education than those provided by universities, the lack of coherence between the universities and the polytechnics persists as a weakness of both systems. The universities, the more senior of the partners, should acknowledge that it is, in these hard times, for them to bridge the gap. While they are about it, they should also give more serious thought than has been their habit to the needs of their students and of their students' potential employers. British students are too highly specialized; British graduates are too uniformly academic. Not all but most universities should change their habits of selection and their ways of teaching so as to cater for a greater diversity of people and of interests. Over the past twenty years, British universities (singly and collectively) have resisted the notion that students are not all ideally the same, and that students' ambitions sometimes encompass secularly non-academic goals. That is obscurantist.

The plain truth about the distant future is that British universities are at present organized in such a way that they will all (except Oxbridge) sink together unless they have the courage to acknowledge that survival requires that they should exercise the autonomy of which they boast. Several corollaries arise. Academics should not always be paid the same, under "nationally negotiated agreements"; instead, universities should be free to pay their people what they can afford (and earn). Tenure should be limited, taking some account of the need to preserve people's freedom to write (and even to say) what they think fit, but acknowledging that universities cannot make lifelong contracts with their employees while living from hand to mouth themselves. The result of such an erosion of the common academic sense of security would send the better academics flocking to two contrasting kinds of places - secure universities valued for their sheer academic excellence and much more specialized places valued for their special skills at teaching students what much of the real world expects of them. The result, of course, would be more diversity among institutions of higher education. Would that necessarily be disastrous? The system as it is is calamitously uniform.

So how to get from here to there? The interpretation of the British government's budget restrictions by the University Grants Committee will, if unchanged, have an ossifying effect. Universities individually will preserve their present character but will shrink. Strange though it may seem, the universities probably find that dismal prospect preferable to the better alternative - a framework in which they would be enabled but also compelled to find for themselves a niche in the market in higher education. 